\title{
Use of an optimal and distinctive method for the extraction of genomic DNA from Juniperus excelsa of the Zarghoon Juniper ecosystem in Balochistan, Pakistan
}

\author{
Zahoor Ahmed Bazai ${ }^{*}$, Rasool Bakhsh Tareen ${ }^{1}$, Muhammad Younas \\ Khan Barozai ${ }^{1}$, Humma Batool ${ }^{2}$, Abdul Kabir Khan Achakzai ${ }^{1}$ and \\ Basira Akhtar ${ }^{1}$ \\ 1. Department of Botany, University of Balochistan, Quetta (87300), Pakistan \\ 2. Department of Botany at the SBK, Women University, Quetta (87300) Pakistan. \\ *Corresponding author's email: $\underline{\mathrm{z} \text { bazai@yahoo.com }}$ \\ Citation \\ Zahoor Ahmed Bazai, Rasool Bakhsh Tareen, Muhammad Younas Khan Barozai, Humma Batool, Abdul Kabir \\ Khan Achakzai and Basira Akhtar. Use of an Optimal and Distinctive Method for the Extraction of Genomic DNA \\ of Juniperus excelsa at the Zarghoon Juniper Ecosystem in Balochistan, Pakistan. Pure and Applied Biology. Vol. 4, \\ Issue 4, 2015, pp 659-663. http://dx.doi.org/10.19045/bspab.2015.44026
}

\begin{tabular}{lll}
\hline \hline Received: 15/09/2015 & Revised: 13/11/2015 & \\
\hline
\end{tabular}

\section{Abstract}

This exploration was carried out through field inspection in immediate forest neighborhoods of two settlements entitled Killi Tor Shore (K.T.S.) and Killi Shaban (K.S.) in revision region Zarghoon Juniper ecosystem, three districts named Quetta, Sibi and Ziarat, province Balochistan, Pakistan. The leaf samples of Juniperus excelsa trees were collected from these areas and subjected for the DNA isolation. As no genetic analysis is reported for this area Juniper, thus this study is aimed to optimize a protocol for the extraction of DNA. In order to isolate high aggregate of pure and intact DNA would serve great base for the downstream genetic analyses. The impurities of plants predominantly the pine trees are owing to the existence of high magnitude of secondary metabolites, polyphenols and polysaccharides. After the application of different acknowledged protocols for the DNA extraction of Juniperus excelsa trees it was perceived none of the protocols extracted pure and high yield DNA. Therefore, with the adaptation in technique an optimized protocol abetted in isolating pure DNA chiefly for tree Juniperus excelsa. This optimized protocol applied multiple times consequently made possible the isolation of pure DNA of Juniper.

Key words: Ziarat Juniper; DNA extraction; Secondary metabolites.

Introduction

Fortication and Conservation of forests is a significance constituent of environmental policies in numerous countries. Genetic diversity is intact quantity of innate features in the genome of a species or a population. Populations in different surroundings and species within populations may have 
different genetic characteristics [1, 2].

Consequently, to study genetic interactions of species within populations and amongst populations in dissimilar environment is the substance for administration of flora. Biotechnology involvement to affluence in scrutinizing genetic mannerisms of an individual species in different environmental conditions is prodigious. Seedlings planted in arid or semi-arid areas should have a well-developed root system for better absorption of water lost from the soil in shoots and leaves [3, 4]. Juniper forest functioning as an essential source of wood for construction, food preparation and fuel over ages but they are subjected to over exploitation, substantial grazing and fires; while silivi-cultural practices or other management practices are lacking. Juniper is the most prominent type of vegetation at or above $1600 \mathrm{~m}$ elevation [5, 6]. Junipers can endure deprived soils and persist at exceedingly high and low temperatures in contrast to other forest trees. In addition, they are extremely resilient and they are the latest species that abandon areas in the course of deforestation [7]. Afforestation revisions on juniper documented that seedlings with low shoot/root fresh or dry weight provided healthier results, chiefly in scorched areas $[8,9]$. Biodiversity has three components and genetic diversity is one of the portions of biodiversity, and therefore is significant in conservation. Conservation of forests is important content of biodiversity conservation [10]. The objective of this study was to test the hypothesis that Juniperus excelsa did not endorse intact and high yield of DNA from one isolation protocol. Therefore, numerous protocols for DNA extraction were applied to many plant species [11 - 13]. These were modified and a suitable method formulated which is discussed below.

\section{Materials and Methods}

In Zarghoon Juniper forest leaf samples of total eight trees as per four samples from growth vicinity named Killi Tor Shore and Killi Shaban collected for DNA isolation (Table 1).

Table 1. List of location, altitude, collection date, and University of Balochistan Botany Herbarium (UoBBH) voucher number of Juniperus samples used in this study.

\begin{tabular}{|c|c|c|c|c|}
\hline SPECIES & LOCATION & Alti $(\mathbf{m})$ & COLLECTD & VOUCHER \# \\
\hline$J$. excels & Killi Tor Shor & 2400 & $20-7-11$ & UoBBH201 \\
\hline$J$. excels & Killi Tor Shor & 2400 & $20-7-11$ & UoBBH202 \\
\hline$J$. excels & Killi Tor Shor & 2400 & $20-7-11$ & UoBBH203 \\
\hline$J$. excels & Killi Tor Shor & 2400 & $20-7-11$ & UoBBH204 \\
\hline J. excels & Killi Shaban & 3200 & $27-7-11$ & UoBBH205 \\
\hline$J$. excels & Killi Shaban & 3200 & $27-7-11$ & UoBBH206 \\
\hline$J$. excels & Killi Shaban & 3200 & $27-7-11$ & UoBBH207 \\
\hline$J$. excels & Killi Shaban & 3200 & $27-7-11$ & UoBBH208 \\
\hline
\end{tabular}

\section{DNA isolation protocol}

Fresh leaf samples were used for DNA isolation by the modified PVP method [14] owing to its appropriateness to Juniperus excelsa. Eight gram of leaf sample from each tree were pulverized in liquid nitrogen and grinded using pestle and mortar. An extraction buffer consisting of $2 \%$ CTAB (w/v), $\mathrm{NaCl}(2 \mathrm{M}), 150 \mathrm{mM}$ Tris- $\mathrm{HCl} \mathrm{pH}$ 8.0 and $30 \mathrm{mM}$ EDTA pH 8.0 was prepared. After being autoclaved for $20 \mathrm{~min}, 3 \% \mathrm{PVP}$ (w/v), 2\% (v/v) 2-mercaptoethanol and 2\% SDS (w/v) were added to the extraction buffer. Almost 100mg grinded tissue was 
taken in $1.5 \mathrm{ml}$ tubes with $1.2 \mathrm{ml}$ of extraction buffer. Eppendorf tubes were mixed by vortex and incubated for $10 \mathrm{~min}$ at $60^{\circ} \mathrm{C}$ and centrifuged at $12,000 \mathrm{rpm}$ for 15 $\min$ at RT (room temperature). The supernatant was transferred to a new $1.5 \mathrm{ml}$ Eppendorf tube and extracted with equal volume of chloroform: isoamyl alcohol $(24: 1, v / v)$. Carefully the supernatant was carried out into a new $1.5 \mathrm{ml}$ tube and an equal volume of basic Phenol: Chloroform: Isoamyl alcohol (PCI 25:24:1, v/v/v) was added and vigorously mixed. The tubes were centrifuged for $15 \mathrm{~min}$ at $12000 \mathrm{rpm}$. To remove the entire proteins and other organic phase soluble contaminants the PCI extraction was repeated once more. Then took supernatant into new tubes and added twice volume of $100 \%$ ethanol. To precipitate the genomic DNA $20 \mu \mathrm{l}$ of $5 \mathrm{M}$ sodium acetate was added to each tube and kept overnight at $-20^{\circ} \mathrm{C}$. After overnight incubation the tubes were centrifuged for
$10 \mathrm{~min}$ at $12000 \mathrm{rpm}$. The pellet was then washed with $70 \%$ ethanol and air dried. The pellet was dissolved in $30 \mu \mathrm{l}$ double distilled deionized water and kept at $-20^{\circ} \mathrm{C}$.

Confirmation on gel electrophoresis and spectrophotometer

The quantitative and qualitative analyses of DNA was performed by measuring optical density at $260 \mathrm{~nm}$ and $280 \mathrm{~nm}$ using Genova Nano spectrophotometer. Polysaccharide contamination was determined by maximum absorbance measurement at $230 \mathrm{~nm}$. Ratio measurements at wavelengths 230, 260 and 280 indicated degree of DNA purity. The absorption ratio A260/230 indicated polysaccharide/polyphenolic contaminants and A260/280 indicated protein contaminates. The DNA were loaded on a $1 \%$ agarose gel, stained with ethidium bromide (EtBr) electrophoresed and visualized under UV light to assess the integrity of DNA $[15,16]$.

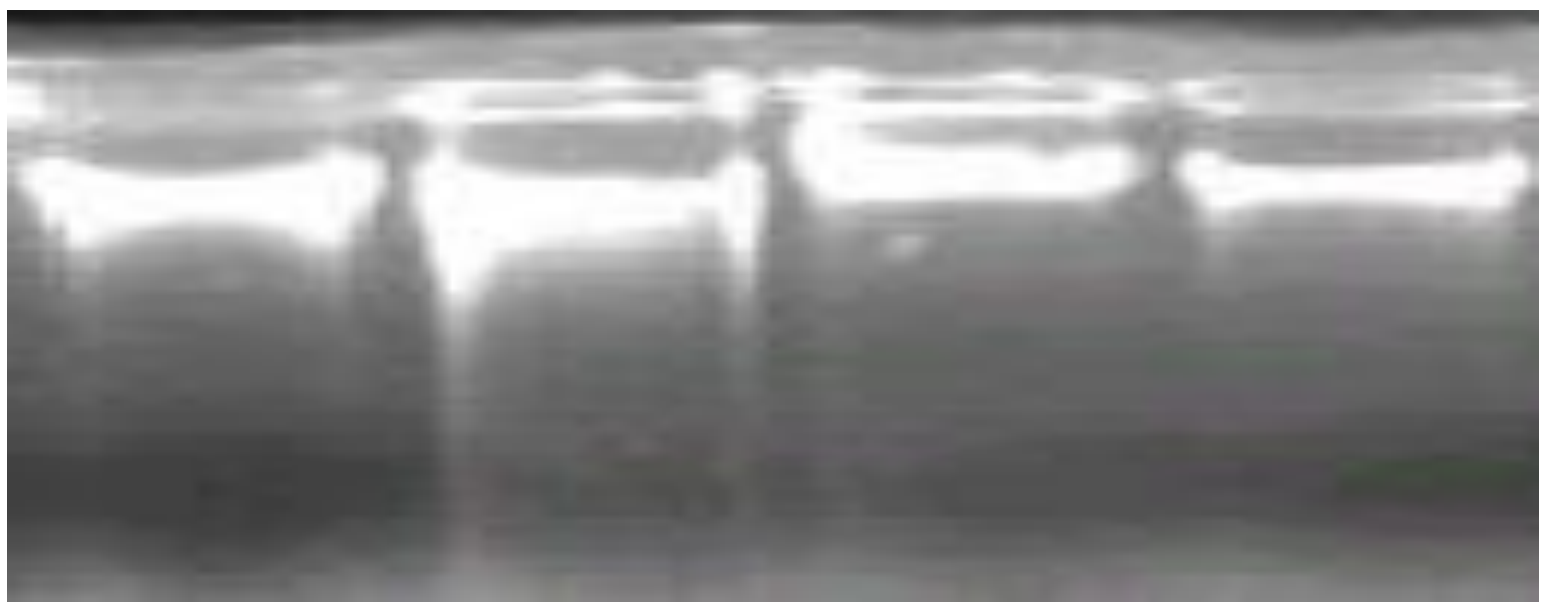

Figure 1. Total Genomic DNA was extracted from the leaf of Juniper tree (Juniperus excelsa) and run on 1\% agarose gel, stained with ethidium bromide, showing intact DNA bands

\section{Results \& discussions}

In the beginning, the isolation of DNA was conducted using the available procedures from the survey of literature, but found that these methods could not remove polyphenolics from the Juniper tree tissues, and that no DNA was extracted [11]. In this study a modified method was used to isolate the genomic DNA from Juniperus excelsa containing high amounts of polysaccharides 
and phenolic compounds. Similar study was done by Michiels et al., [17] in latexcontaining plants and Japelaghi et al., [18] in different plant tissues that contain large amounts of polysaccharides and polyphenol compounds. Compared with the existing method, we have isolated DNA from Juniper in considerable quantity and in intact form (Fig-1). The isolated DNA was of high quality as it showed a reading in between 1.7 to 1.9 after calculating the ratio of absorbance $260 / 280 \mathrm{~nm}$. Later on all of these DNAs were used for PCR analysis in a separate study. This DNA preparation method yielded a predominance of high molecular weight DNA. Considering all factors involved, this method appears to be the most efficient, reliable and laboreffective DNA isolation procedure from Juniper tree containing a high content of polyphenolics.

\section{Acknowledgment}

The Research was conducted in Biotech Lab, Department of Biotechnology, University of Balochistan, Pakistan. The Research Team is thankful for the provision of lab facility. The Financial support by Higher Education Commission (HEC), Pakistan is highly acknowledged.

\section{Authors' contributions}

Conceived and designed the experiments: RB Tareen \& ZA Bazai. Performed the experiments: MYK Barozai \& ZA Bazai. Analyzed the data: AKK Achakzai \& H Batool. Contributed reagents/ materials/ analyses tools: B Akhtar. Wrote the paper: ZA Bazai.

\section{References}

1. Karimi R, Kafkas S, Zamani Z, \& Ebadi A (2009). Genetic relationships among Pistacia species using AFLP markers. Plant Syst. Evol. 2(9): 21-28.

2. Kim S, Lee C. H, Shin1 J. S, Chung1 Y. S \& Hyung N. I (1997). A simple and rapid method for isolation of high quality genomic DNA from fruit trees and conifers using PVP, Oxford University Press Nucleic Acids Research 25(5): 1085-1086.

3. Hermann R (1964). Importance of top-root ratios for survival of douglas-fir seedlings, Tree Planters Notes, 64: 711.

4. Baer, N (1977). Effects of watering, shading, and size of stock on survival of planted lodgepole pine, USDA Forest Serv., Rocky Mt., Forest and Range Exp. Sta., Fort Collins, Colorado, Tech. Rep.

5. Hobbs B.R. H. D, \& Freost C (1980). First year performance of 1-0 containerized douglas-fir seedlings on droughty sites in southwestern Oregon, Oregon State Univ., Forest Res. Lab., Corvallis, Res. Pap. 42.

6. Chaudhary S (1997), Flora of the kingdom of saudi arabia," National Agriculture and Water Research Centre, Ministry of Agriculture, Saudi Arabia, Tech. Rep.

7. Pamay B (1955), Turkiye ardic turleri ve yayililari," U Orman Fakultesi Dergisi, Tech. Rep.

8. Yahyaolu Z \& Genc M. (2007). Fidan standardizasyonu, standart fidan yetitirmenin biyolojik ve teknik esaslari," SDU Fakultesi Yayini, Isparta, Turkey. Tech. Rep.

9. Gultekin H (2007). Turkiye ardic (juniperus 1.) turlerinin ekolojisi ve silvikultur teknikleri. orman muhendisleri odasi yayini, Ankara, Turkey, Tech. Rep.

10. Kate KT, Laird SA (1999). The commercial use of biodiversity. Earthscan Publications Ltd., London.

11. Kim C. S. Lee C. H. Shin1 J. S., Chung1 Y. S. \& Hyung N. I. (1997). A simple and rapid method for isolation of high quality genomic DNA from fruit trees and conifers using PVP. Nucleic Acids Research 25(5): 1085-1086. 
12. John, M.E. (1992) Nucleic Acids Res. 20, 2381.

13. Steiner, J.J., Poklemba, C.J., Fjellstrom, R.G. and Elliottt, L.F. (1995) Nucleic Acids Res. 23, 2569-2570.

14. C. S. Kim, C. H. Lee, J. S. Shin1,*, Y. S. Chung1 and N. I. Hyung2.

15. Duffy KJ, Scopece G, Cozzolino S, Fay MF, Smith RJ, Stout JC (2009). Ecology and genetic diversity of the dense-flowered orchid, Neotinea maculata, at the centre and edge of its range. Ann. Bot. 104: 507-516.

16. Sambrook J, Fritsch EF, Maniatis $T$ (1989). Molecular cloning: A laboratory manual. Cold Spring Harbor Laboratory
Press, Cold Spring Harbor, New York, USA.

17. Michiels, A., Van den Ende, W., Tucker, M., Van Riet, L., \& Van Laere, A. (2003). Extraction of high-quality genomic DNA from latex-containing plants. Analytical biochemistry, 315(1), 85-89.

18. Japelaghi, R. H., Haddad, R., \& Garoosi, G. A. (2011). Rapid and efficient isolation of high quality nucleic acids from plant tissues rich in polyphenols and polysaccharides. Molecular biotechnology, 49(2), 129137. 